\title{
Pursuit-diving seabird endures regime shift involving a three-decade decline in forage fish mass and abundance
}

\author{
William A. Montevecchi ${ }^{1, *}$, Kara Gerrow ${ }^{1}$, Alejandro D. Buren ${ }^{2}$, Gail K. Davoren ${ }^{3}$, \\ Keith P. Lewis ${ }^{2}$, Marina W. Montevecchi ${ }^{1}$, Paul M. Regular ${ }^{2}$ \\ ${ }^{1}$ Psychology and Biology Departments, Memorial University of Newfoundland, St. John's, NL A1C 5S7, Canada \\ ${ }^{2}$ Fisheries and Oceans Canada, St. John's, NL A1A 5S7, Canada \\ ${ }^{3}$ Department of Biological Sciences, University of Manitoba, Winnipeg, MB R3T 2N2, Canada
}

\begin{abstract}
Forage species availability is a key determinant of seabird success, survival, and population change. In the Northwest Atlantic Ocean, capelin Mallotus villosus, a keystone forage species, experienced a stock collapse in the early 1990s that was a pivotal component of a regional regime shift. Since then, capelin have exhibited delayed protracted spawning, younger spawning age, distribution shifts, and smaller size. As capelin specialists, pursuit-diving common murres Uria aalge have had to adjust to these changes. We show that the masses of capelin provisioned to murre chicks at the species' largest colony declined steadily from 1990-2017. We predicted that the parental provisioning of lower quality prey would reduce offspring condition, lower parental body mass, and increase foraging effort. Offspring condition declined, and while no negative effects were found on adult body mass, parental murres worked substantially harder in 2016, when capelin were dispersed and availability was low and when offspring and parental mass were the lowest in the time-series. These circumstances suggest that the murres neared a behavioral tolerance of parental effort. Despite the multi-decadal order-of-magnitude reduction in the regional capelin stock, parental murres coped by exploiting local prey availability at persistent shallow-water spawning sites and by increasing foraging effort. Even while the keystone forage fish stock remained at extremely low levels, the murre population increased, a likely consequence of enhanced adult survival due to amelioration of anthropogenic risk factors.
\end{abstract}

KEY WORDS: Forage fish · Seabirds · Prey availability · Prey quality · Foraging behavior • Provisioning $\cdot$ Predator · Resiliency

\section{INTRODUCTION}

How marine top predators respond to ocean climate change is a focal research question that challenges biologists, oceanographers, and fishers alike. Ocean climate influences on top predators are mediated almost exclusively through bottom-up influences on prey availability (Oro 2014), and forage species on which many top predators depend are often the conduit of food web perturbations which can generate complex species interactions (Sydeman et al. 2015).

\footnotetext{
*Corresponding author: mont@mun.ca
}

Capelin Mallotus villosus, a keystone forage species in the Northwest Atlantic Low Arctic ecosystem, collapsed by an order of magnitude during a regime shift in the early 1990s (Buren et al. 2014). In Northwest Atlantic Fisheries Organization (NAFO) Divisions 3KL, stock biomass declined from approximately 3000-6000 kt before 1991 to 23-983 kt from 1991-2017 (DFO 2018, Buren et al. 2019). Subsequently, capelin have exhibited delayed and protracted seasonal spawning, spawned at younger ages, and shown spatial shifts and decreased size

(C) W. A. Montevecchi, K. Gerrow, G. K. Davoren, M. W. Montevecchi, and Fisheries and Oceans Canada 2019. Open Access under Creative Commons by Attribution Licence. Use, distribution and reproduction are unrestricted. Authors and original publication must be credited. Publisher: Inter-Research · www.int-res.com 
owing to the disappearance of older age classes (Buren et al. 2019).

Given these changes in capelin availability and behavior, breeding seabirds are predicted to exhibit non-linear responses across a range of behavioral and population parameters before reaching a tipping point (Cairns 1987). For example, breeding success can be nearly constant over a wide range of prey abundances, in part because seabirds often exhibit behavioral flexibility to counter prey base deterioration, e.g. by increasing foraging time through reduction in discretionary time at the colony (Burger \& Piatt 1990, Grémillet et al. 2012, Regular et al. 2014). However, below a certain level of prey availability, breeding success can decline precipitously (Harding et al. 2007, Piatt et al. 2007).

A global meta-analysis has suggested that a threshold for seabird productivity occurs at approximately of the long-term maximum biomass of the key prey species (Cury et al. 2011). For central place foragers like colonial nesting seabirds, however, it is necessary to consider fish stocks assessed at large scales and actual food supply (i.e. locally available prey within the predators' foraging range; Guillemette et al. 2018), as large changes in stock size may not be realized at local scales due to range contractions (Worm \& Tittensor 2011) or to locally persistent high-abundance aggregations related to key life history events such as spawning (Penton \& Davoren 2012, Davoren 2013b). Hence, the prey base around a seabird colony could remain locally abundant even if the fish stock declined regionally. In addition to food availability, prey quality can also influence breeding success by compelling predators to catch more prey to compensate for less energetically beneficial food (junk food hypothesis; Österblom et al. 2008, Kadin et al. 2016). Interactions between local prey availability and quality can therefore complicate the relationship between seabird breeding productivity and regional stock size.

The largest North American colony of the common murre Uria aalge (hereafter murre), on Funk Island, Newfoundland, Canada (Nettleship \& Evans 1985), is an excellent site to examine how seabirds respond to marked differences in food supply and prey quality. Murres are the primary seabird predator of capelin in the Northwest Atlantic (Montevecchi 2000) and are capelin specialists (Davoren \& Montevecchi 2003). Their breeding season overlaps with the inshore spawning period of capelin (Regular et al. 2014), and they are sensitive samplers of inter-annual variation in capelin availability (Davoren \& Montevecchi 2003, Burke \& Montevecchi 2009, Buren et al. 2012, Davoren et al. 2012).
Despite the collapse of the capelin stock, spawning sites in shallow water (15-40 m) that are accessible to murres have been persistent within the murres' foraging range $(60-80 \mathrm{~km})$ around Funk Island (Burke \& Montevecchi 2009, Hedd et al. 2009, Penton \& Davoren 2012, Davoren 2013a). These sites, where capelin can be predictably located, are key foraging areas for marine birds and mammals (Davoren 2013b).

Here, we investigated how the order-of-magnitude decrease in capelin biomass and changing fish mass influenced the murres' parental food deliveries, offspring condition, and adult body mass over 3 decades (1990-2017; see Davoren \& Montevecchi 2003). To assess parental effort, we compared the foraging tracks of the murres during 2014 - when capelin exhibited multiple spawning waves and biomass was higher in the study area, relative to 2016-when capelin did not spawn during the study period, biomass was lower, and the fish were more scattered.

\section{MATERIALS AND METHODS}

\subsection{Study site}

Research was carried out on the Funk Island Ecological Seabird Reserve $\left(49^{\circ} 45^{\prime} \mathrm{N}, 53^{\circ} 11^{\prime} \mathrm{W}\right)$, a small $(800 \times 400 \mathrm{~m})$, relatively flat granite rock about $40 \mathrm{~km}$ off the northeast coast of Newfoundland, Canada (see Montevecchi \& Tuck 1987). In 2009, 500 000 pairs of common murres bred on the islet (Wilhelm et al. 2015).

\subsection{Capelin sampling from parental prey loads}

Prey were collected from food-carrying parental murres that were captured with pole nets as they flew into the center of the colony. The species, sex, maturity (gravid, spent, immature capelin), digested condition (fresh progressing through eyeless, snoutless, headless), mass ( $\mathrm{g})$, and fork length $(\mathrm{cm})$ of each fish were determined in the hand and recorded using a measuring board and Pesola spring scales during late July/early August 1990 through 2017 (Table S1 in Supplement 1 at www.int-res.com/articles/suppl/ m627p171_supp.pdf). We used all capelin (male and female) that were whole (i.e. digestion $=$ fresh or eyeless) and excluded years when, owing to field logistics, there were fewer than 10 prey samples (1991, 1994, 2010). We analyzed capelin mass, length, and Fulton's condition factor $(K$; a weight-length relationship, see Davoren \& Montevecchi 2003) as a func- 
tion of year (see Supplement 2). To avoid the introduction of biases associated with Fulton's $K$, we decided not to report trends in condition, and because most of the variability in the energy content of capelin delivered to murre chicks is due to the mass of the fish, we focused the analyses on capelin mass (see Supplement 2 for data assessment and rationale). Capelin mass was used as a proxy for prey quality, as this metric reflects the calorific content received by offspring in each prey delivery.

\subsection{Chick and fledgling condition}

Chicks were captured at the same centrally located sub-colony site (1980, 1991-1995, 1997-1998), and fledglings moving to the water with adults at dusk and after dark were captured with dip-nets (1980, 1982-1984, 2000-2005, 2009, 2010, 2012-2014, 2016, 2017; Table S1). Mass was measured to the nearest 2 or $5 \mathrm{~g}$ using 300 or $600 \mathrm{~g}$ Pesola spring scales respectively, and flattened wing lengths were measured to the tip of longest primary wing covert to the nearest $1 \mathrm{~mm}$. Young were banded with US Fish and Wildlife Service (USFWS) metal bands on their right leg and released immediately. The condition of young was calculated by dividing body mass by wing length (Davoren \& Montevecchi 2003). Chick and fledgling data were combined to calculate overall offspring condition (provided as mass per wing length, $\mathrm{g} \mathrm{mm}^{-1}$ ); chicks with wings less than $30 \mathrm{~mm}$ were excluded from analysis (Fig. S1).

\subsection{Adult mass}

Murres carrying capelin and flying in to the central area of the colony were captured with pole nets, weighed with 1000 or $1500 \mathrm{~g}$ Pesola spring scales, and banded (USFWS) on the right leg before immediate release in 1990, 2000, 2005, and 2008-2017 (Table S1). Data from 1990 and 2000 were excluded from analysis owing to differences in data collection (1990) and small sample size $(2000 ; \mathrm{n}=3)$.

\subsection{Tracking foraging parents}

On 31 July 2014, each of 10 parental murres with chicks were captured by noose pole at a centrally located sub-colony and had an Ecotone Telemetry GPS-UFH Uria-60 data logger $(26 \times 16 \times 11 \mathrm{~mm} ; 6 \mathrm{~g})$ taped ( $2 \mathrm{~g}$ ) to scapular and back feathers. Tracking data were downloaded to a base station on the island each time a bird returned to the colony following a foraging trip. Data collection began on 31 July; the base station (containing downloaded data) was removed on 7 August. Due to a logger malfunction during 2014, GPS positions were obtained from 9 birds. In 2016, 6 parental murres with chicks had Ecotone Telemetry GPS-UFH Uria-300 loggers $(36 \times 22 \times$ $12.5 \mathrm{~mm} ; 13.5 \mathrm{~g}$ ) taped ( 2 g) to scapular and back feathers and data were downloaded to a base station on the island during 18-27 July. Devices (<1 \% [2014] and $<2 \%$ [2016] mean annual adult body mass) recorded latitude, longitude, and speed data every $10 \mathrm{~min}$; dive frequency and duration were recorded whenever devices were submerged for $10 \mathrm{~s}$ or more. Data collected from each individual were partitioned into trips by splitting the track between periods when the bird was known to be at the colony. Trips greater than $2 \mathrm{~km}$ ( $72 \%$ of all trips) from the colony were considered foraging trips; trips less than that were excluded from analysis because these trips are likely related to bathing and rafting behavior near the colony (Burger 1997).

\subsection{Capelin biomass and spawning dates}

A fine-scale $(\sim 15 \mathrm{~km})$ hydro-acoustic survey was conducted approximately weekly during July and August 2014 (11, 14, 18, 24 July) and 2016 (14 July, 3, 16 August) over 4 persistently used shallow-water (15-40 m) capelin spawning sites (Penton \& Davoren 2012) as part of an annual monitoring program of the timing and magnitude of peak capelin biomass in the study area. The survey area represents an annually persistent biological hotspot of multiple seabird and whale species, including high abundances of murres (Davoren 2013b). The survey followed a zig-zag design to include each shallow-water spawning site within the survey. Along the survey line, capelin biomass was quantified using a DTX 6000 (BioSonics) scientific echo-sounding system, operated through a $70 \mathrm{kHz}$ split-beam transducer (see Davoren et al. 2006). To quantify capelin biomass $\left(\mathrm{g} \mathrm{m}^{-2}\right)$ per survey, backscatter volume $\left(s_{\mathrm{v}}\right)$ was converted into backscatter area $\left(s_{\mathrm{a}}\right)$, which was then combined with biometrics of capelin in the study area and a published target strength-length relationship for capelin in Newfoundland (Rose 1998). The survey that detected peak average capelin biomass $\left(\mathrm{g} \mathrm{m}^{-2}\right)$ within a year has been used as the most robust metric of interannual differences in forage fish abundance in the seabird foraging areas. Additionally, shallow-water 
spawning sites were monitored for capelin spawning activity (presence of eggs) following methods described in previous studies in the area (Davoren et al. 2012, Penton \& Davoren 2012, Davoren 2013a,b, Crook et al. 2017).

\subsection{Data processing and statistical analysis}

Data processing, analyses, and plotting were conducted using $\mathrm{R}$ version 3.4.2 (R Core Team 2017). In addition to base $\mathrm{R}$, the 'data.table' (Dowle \& Srinivasan 2017) package was used to aid data processing and the 'sf' (Pebesma 2017) and 'ggplot2' (Wickham 2016) packages were used for plotting and mapping. Linear mixed models were run using the 'lme4' package (Bates et al. 2015).

Linear trends in capelin mass, murre offspring condition, and adult murre mass were assessed using a regression of the annual means of each metric and weighted by the inverse of the variance of the annual measurements - a standard approach for accounting for varying quality of point estimates (Faraway 2016).

Total and maximum distances travelled during each foraging trip were extracted from the GPS data. Total distance was simply the cumulative point-to-point distance traveled within a foraging trip, and maximum distance was the maximum point-to-colony distance recorded within a foraging trip. Note that these metrics were underestimated in 2016, especially total distance, because several foraging trips were only partially recorded by the devices. Differences between total and maximum distances travelled per foraging trip across these 2 yr were assessed using a linear mixed model with individual as a random effect.

Means $( \pm \mathrm{SD})$ are presented throughout and parameter estimates from linear models are presented with $95 \%$ confidence intervals in square brackets. Trends are considered significant if the $95 \%$ confidence intervals did not bound zero.

\section{RESULTS}

\subsection{Parental prey deliveries}

Murres on Funk Island specialize on capelin to provision offspring. Over 3 decades (1990-2017), parental food loads consisted almost exclusively of capelin $(93.9 \pm 10.9 \%)$ of which almost all were females $(95.2$ $\pm 5.2 \%$; Fig. 1). The mean annual mass of fresh capelin delivered to chicks declined significantly between 1990 and 2017 (-0.10 [-0.19, -0.017] $\mathrm{g} \mathrm{yr}^{-1}$; Fig. 2A).

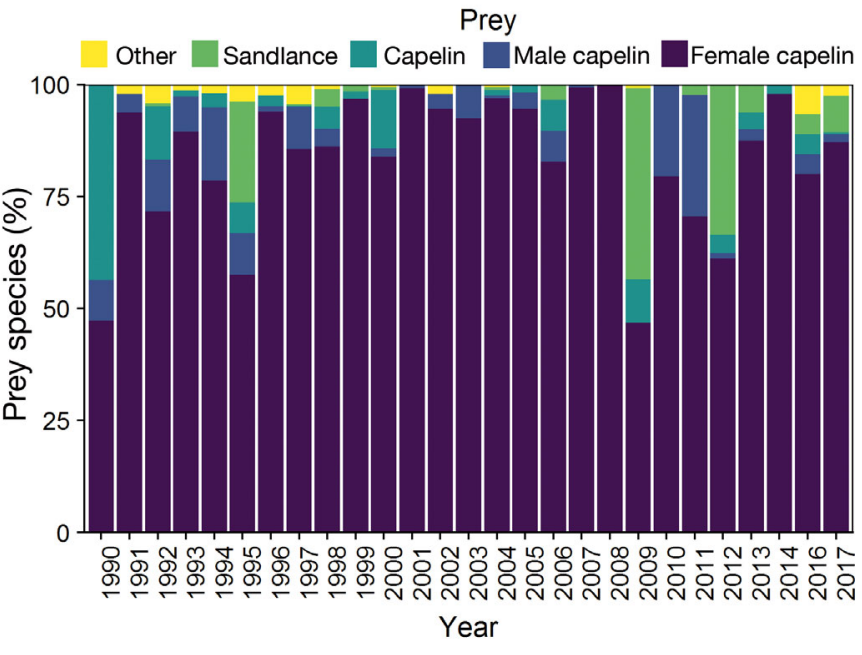

Fig. 1. Percentage of prey species provisioned to common murre chicks on Funk Island, NL, 1990-2017

\subsection{Offspring condition and adult mass}

Murre offspring condition also declined over the time series $\left(-0.032[-0.055,-0.010] \mathrm{g} \mathrm{mm}^{-1} \mathrm{yr}^{-1}\right.$; Fig. 2B). The mean body mass of food-provisioning parental murres exhibited considerable variation and did not change systematically from 2005-2017 (-0.92 [-2.77, 0.93] $\mathrm{g} \mathrm{yr}^{-1}$; Fig. 2C).

\subsection{Parental foraging and diving effort}

Compared to 2014, parental murres doubled their maximum and total foraging distances from the colony in 2016 (Table 1, Fig. 3). The average maximum distance travelled from the colony per foraging trip in 2016 was 28.7 [8.6-50.2] $\mathrm{km}$ further than parental murres traveled in 2014 (i.e. a 102\% increase). Likewise, total distance traveled per foraging trip in 2016 was significantly longer than in 2014 (difference $=61.6[15.0-109.1] \mathrm{km}$; a $94 \%$ increase). As well as traveling farther to forage in 2016, parental murres also dove much more frequently in 2016 (108.1 \pm 30 dives per foraging trip) than in 2014 (44.6 \pm 13 dives per foraging trip; $t=3.91$, $\mathrm{df}=53.81$, $\mathrm{p}=0.0003$; Fig. 4), and mean maximum dive duration was also significantly longer in $2016(216.8 \pm 22.5 \mathrm{~s}$ [3.6 min]) than in $2014(162.3 \pm 20.31 \mathrm{~s}$ [2.7 $\mathrm{min}] ; t=$ 3.61, df = 85.64, p = 0.0005; Fig. 5).

Coincident with the inter-annual differences in foraging behavior and parental effort, in 2014 average fledgling condition $\left(3.28 \pm 0.72 \mathrm{~g} \mathrm{~mm}^{-1}\right)$ and parental mass $(934.6 \pm 6.1 \mathrm{~g})$ were significantly higher than fledgling condition $\left(2.49 \pm 0.36 \mathrm{~g} \mathrm{~mm}^{-1}\right)$ and parental 



Fig. 2. (A) Capelin mass and (B) common murre offspring condition and (C) adult mass on Funk Island. Error bars $=$ SDs; grey shading $=95 \%$ CI of the slope of the linear regression

mass $(908.2 \pm 5.6 \mathrm{~g})$ in 2016 , when both factors were the lowest in their respective data series. For the $5 \mathrm{yr}$ for which we have both offspring condition and local level prey data $(2010,2012,2014,2016,2017)$, there is a suggestive positive correlation between offspring condition and peak capelin biomass $(\mathrm{r}=$ $0.44, \mathrm{R}^{2}=0.19$ ). The mean masses of GPScarrying birds in $2014(912.8 \pm 34.6)$ were less than those in $2016\left(985.8 \pm 64.7 ; t_{13}=\right.$ $2.86, \mathrm{df}=13, \mathrm{p}=0.13$ ). The masses of the capelin provisioned to chicks did not differ between the $2 \mathrm{yr}$ (2014: $11.5 \pm 3.5 \mathrm{~g}$; 2016: $11.5 \pm 4.1 \mathrm{~g})$.

The timing of fine-scale capelin surveys overlapped during 2014 (11 July: $24, \mathrm{n}=4$ surveys) and 2016 (14 July16 August, $\mathrm{n}=3$ surveys) as did monitoring for capelin spawning activity (2014: 1 July-20 August; 2016: 1 July-16 August). The survey with the peak average capelin biomass in the study area occurred on the same date in both years (14 July) but was higher in 2014 (0.254 g $\mathrm{m}^{-2}$ ) relative to $2016\left(0.027 \mathrm{~g} \mathrm{~m}^{-2}\right)$. Capelin spawned in the study area from 16-24 July 2014, but capelin did not spawn or spawned much later (i.e. after 16 August) in the study area during 2016.

\section{DISCUSSION}

Parental flexibility can be crucial for successful reproduction by seabirds, especially when coping with fluxes in prey availability (Harding et al. 2007, Pettex et al. 2012). Single-prey loading parental murres breeding in the species' largest North American colony specialize on capelin for provisioning offspring but also exhibit foraging flexibility to adjust to variable prey conditions. Yet despite the parental murres' ability to adjust to adverse conditions by foraging farther and delivering larger capelin when prey availability is low (Burke \& Montevecchi 2009, Buren et al. 2012), parents provisioned offspring with smaller capelin over the past 3 decades with concordant decreases in offspring condition.

Table 1. Mean (95\% confidence intervals) of mean maximum and mean total foraging trip distances, offspring condition and adult mass of common murres breeding on Funk Island during 2014 and 2016

\begin{tabular}{|ccccc|}
\hline Year & $\begin{array}{c}\text { Max. foraging distance trip }{ }^{-1} \\
(\mathrm{~km})\end{array}$ & $\begin{array}{c}\text { Total foraging distance trip }{ }^{-1} \\
(\mathrm{~km})\end{array}$ & $\begin{array}{c}\text { Fledgling condition } \\
\left(\mathrm{g} \mathrm{mm}^{-1}\right)\end{array}$ & $\begin{array}{c}\text { Adult mass } \\
(\mathrm{g})\end{array}$ \\
\hline 2014 & $28.1(14.9-40.4)$ & $65.5(36.9-94.4)$ & $3.39(3.23-3.57)$ & $934.7(922.6-947.1)$ \\
2016 & $56.8(23.5-90.6)$ & $127.0(52.0-203.5)$ & $2.49(2.37-2.65)$ & $908.2(897.2-919.0)$ \\
\hline
\end{tabular}


A) 2014

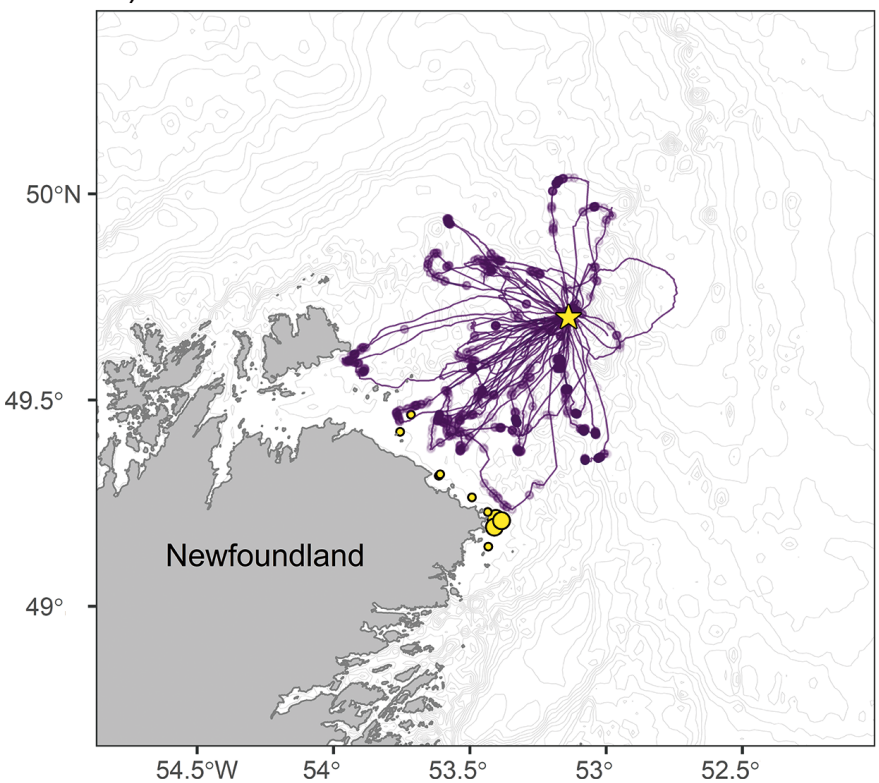

B) 2016

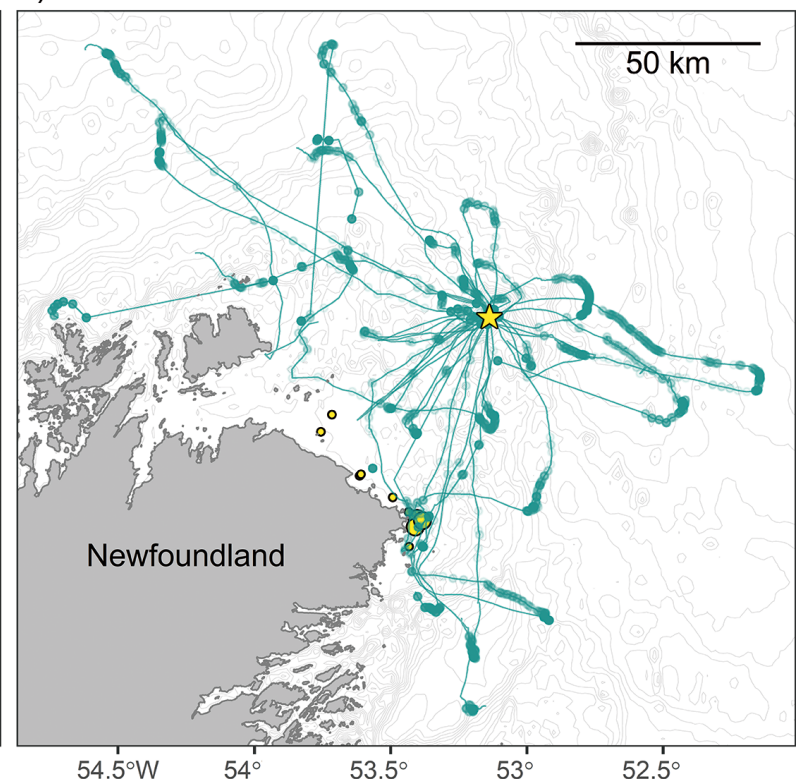

Fig. 3. Common murre foraging trips and dive locations obtained from GPS data for (A) 2014 ( $n=9$ ), when capelin spawned within the murres' foraging range and (B) $2016(\mathrm{n}=6)$, when no spawning was recorded and capelin were more dispersed. Yellow star: Funk Island; yellow circles: locations of shallow-water spawning sites scaled to relative abundance indices (larger circles indicate persistent sites)

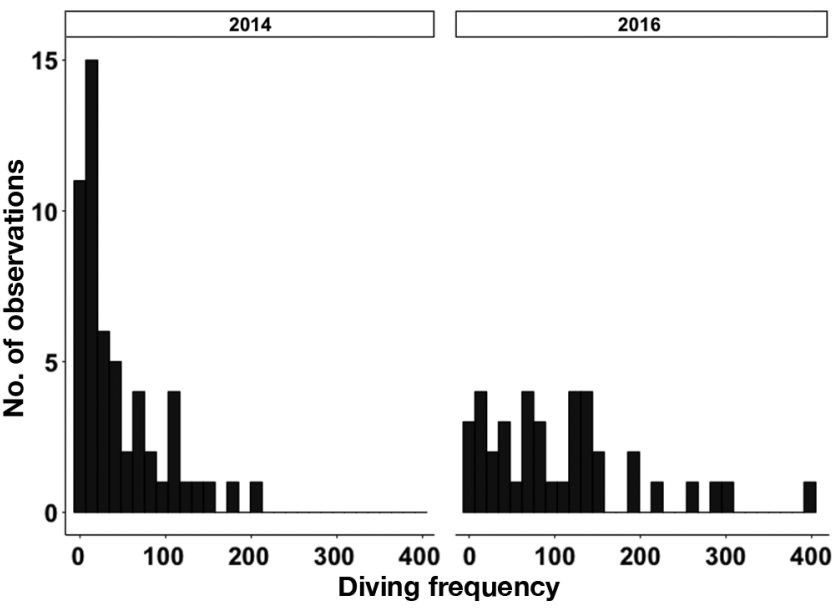

Fig. 4. Diving frequency per foraging trip by parental common murres foraging from Funk Island in 2014 and 2016

The decline in the mass of capelin provisioned to chicks reflects the regional trend, i.e. spawning capelin have become smaller since the early 1990s owing to the disappearance of older age classes (DFO 2018, Buren et al. 2019). Parental murres responded proactively to changes in prey availability by doubling foraging trip lengths, increasing both the frequency and duration of diving in 2016, when capelin biomass was low in key foraging areas compared to 2014. Both offspring condition and adult mass were the lowest on record during 2016, suggesting that the behavioral

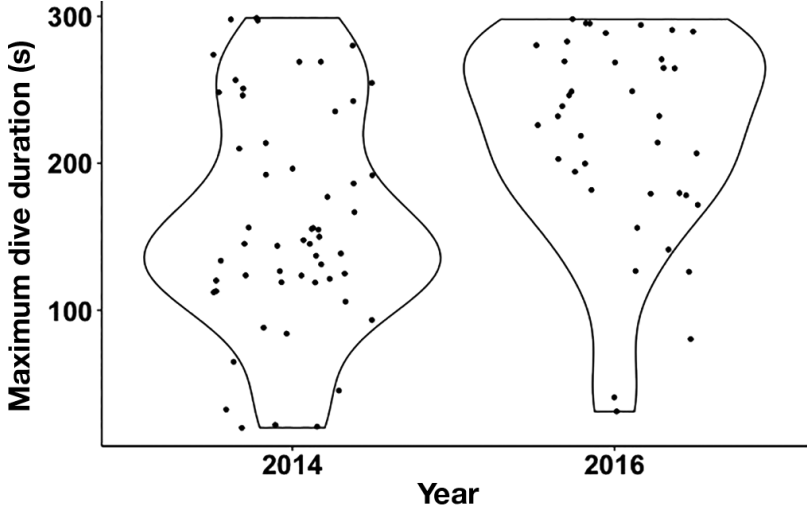

Fig. 5. Violin plot of the maximum dive duration per foraging trip by parental common murres breeding on Funk Island in 2014 and 2016

tolerance of parents was challenged by decreases in capelin availability and mass.

The murres' performance at Funk Island appears to be maintained by nearby predictable and annually persistent high-biomass shoals of spawning capelin (Davoren et al. 2003, Davoren 2013a,b, Gulka et al. 2017). In related circumstances, enhanced foraging effort on locally available prey allowed northern gannets Morus bassanus to maintain breeding success until the availability of its primary prey (Atlantic mackerel Scomber scombrus) 
was only about $8 \%$ of local maximum abundance (Guillemette et al. 2018).

Despite deteriorating offspring condition, the murres' breeding population has increased over the past 35 yr (Wilhelm et al. 2015) following the collapse of the capelin stock. The increase in murre numbers indicates that seabirds can, at times, overcome major declines in fish stocks which, in the current circumstances, was associated with release from gillnet bycatch mortality following the northern cod Gadus morhua and Atlantic salmon Salmo salar fishery closures in the early 1990s (Regular et al. 2013) and with the easement of other negative anthropogenic influences associated with hunting and ship source oil pollution (Wilhelm et al. 2009).

The timing of prey availability can be a key determinant of seabird reproductive success (Regular et al. 2014), and parental deliveries of high quality gravid capelin have been linked to the timing of spawning (Davoren et al. 2012). Temporal mismatches between chick rearing and the peak of abundance in locally spawning capelin likely negatively affect breeding success (Regular et al. 2014, Storey et al. 2017). Owing to the highly variable timing of capelin spawning in our study area (Crook et al. 2017), our temporally restricted sampling period could not adequately assess the potential influence of spawning time on murre responses, though these interactions are likely at play (Davoren et al. 2012).

Despite the apparent resiliency of the common murre population, we caution that the massive colony on Funk Island is quite vulnerable given its size, concentration of breeding adults, and dependency on local capelin spawning sites. As capelin biomass declines, capelin spawn at fewer sites (Crook et al. 2017), resulting in a contraction of critical foraging area for murres and other marine birds, mammals, and fishes. It is uncertain whether the murres on Funk Island are approaching a threshold of parental foraging ability. However, the increased parental foraging efforts and the lowest levels of fledgling condition and adult mass in our $29 \mathrm{yr}$ data series during 2016 suggest that years with low capelin biomass have direct, measurable influences on murres and their offspring. Efforts to monitor breeding success are underway (J. Gulka et al. unpubl. data), and long-term monitoring of prey catches and offspring and adult conditions in comparison with changing capelin conditions are continuing.

\section{CONCLUSIONS}

Our findings document the resiliency of a pursuitdiving seabird in the face of an extreme and prolonged reduction in regional forage fish abundance, mass, and condition. The changes since the early 1990s have imposed costs on breeding murres. Despite these costs, the population has increased at the common murres' largest North American colony - likely due to a local, dependable source of persistent, predictable prey during the breeding season, as well as flexible parental behavior and reductions in adult mortality outside the breeding season. These results underscore the murres' behavioral tolerance, vulnerability, and risk.

Acknowledgements. Valued collaborators who have been instrumental in executing this long-term research program are Chantelle Burke, Pierre Ryan, and the Easton family and fishing crews of Carmanville and Musgrave Harbour, Newfoundland. Some of the data in this paper were presented at the Iceland Workshop on pursuit-diving seabirds (March 2017) and at the Atlantic Society of Fisheries and Wildlife Biologists annual meeting (September 2016). Lindsay-Ann Bellows and Jessika Lamarre assisted with manuscript preparation. Research support was provided by NSERC Discovery and Ship Time grants to W.A.M. and G.K.D., a grant from the World Wildlife Fund and a Memorial University of Newfoundland University Summer Research Assistantship (USRA) to K.G. Research was conducted in accordance with the Canadian Council on Animal Care ethical guidelines and approved by Memorial University of Newfoundland's Institutional Animal Care Committee (Permit Numbers: 1001-WM - 16-01-WM). Fieldwork was carried out under a Canadian Wildlife Service Migratory Bird Banding permit WAM-10322K. Access to the Funk Island Provincial Seabird Ecological Reserve was permitted through the Newfoundland and Labrador Natural Areas Division.

\section{LITERATURE CITED}

Bates D, Mächler M, Bolker B, Walker S (2015) Fitting linear mixed-effects models using lme4. J Stat Softw 67:1-48

* Buren AD, Koen-Alonso M, Montevecchi WA (2012) Linking predator diet and prey availability: common murres and capelin in the Northwest Atlantic. Mar Ecol Prog Ser 445: 25-35

Buren AD, Koen-Alonso M, Pepin P, Mowbray FK and others (2014) Bottom-up regulation of capelin, a keystone forage species. PLOS ONE 9:e87589

Buren AD, Murphy HM, Adamack AT, Davoren GK and others (2019) The collapse and continued low productivity of a keystone forage fish species. Mar Ecol Prog Ser 616: $155-170$

Burger AE (1997) Arrival and departure behavior of common murres at colonies: Evidence for an information halo? Colon Waterbirds 20:55-65

Burger AE, Piatt JF (1990) Flexible time budgets in breeding common murres: buffers against variable prey abundance. Stud Avian Biol 14:71-83 
Burke CM, Montevecchi WA (2009) The foraging decisions of a central place foraging seabird in response to fluctuations in local prey conditions. J Zool (Lond) 278:354-361

Cairns DK (1987) Seabirds as indicators of marine food supplies. Biol Oceanogr 5:261-271

Crook KA, Maxner E, Davoren GK (2017) Temperaturebased spawning habitat selection by capelin (Mallotus villosus) in Newfoundland. ICES J Mar Sci 74:1622-1629

* Cury PM, Boyd IL, Bonhommeau S, Anker-Neilsen T and others (2011) Global seabird response to forage fish depletion - one-third for the birds. Science 334:1703-1706

Davoren GK (2013a) Divergent use of spawning habitat by male capelin (Mallotus villosus) in a warm and cold year. Behav Ecol 24:152-161

Davoren GK (2013b) Distribution of marine predator hotspots explained by persistent areas of prey. Mar Biol 160:3043-3058

* Davoren GK, Montevecchi WA (2003) Signals from seabirds indicate changing biology of capelin. Mar Ecol Prog Ser 258:253-261

Wavoren GK, Montevecchi WA, Anderson JT (2003) Search strategies of a pursuit-diving seabird and the persistence of prey patches. Ecol Monogr 73:463-481

Davoren GK, Anderson JT, Montevecchi WA (2006) Shoal behaviour and maturity relations of spawning capelin (Mallotus villosus) off Newfoundland: demersal spawning and diel vertical movement patterns. Can J Fish Aquat Sci 63:268-284

* Davoren GK, Penton P, Burke CM, Montevecchi WA (2012) Linking water temperature, the timing of capelin spawning and seabird diets to monitor ocean climate in northeastern Newfoundland. ICES J Mar Sci 69:1234-1241

DFO (Fisheries and Oceans Canada) (2018) Assessment of capelin in SA2 and Divs. 3KL in 2017. DFO Can Sci Advis Sec Sci Advis Rep 2018/030. https://waves-vagues.dfompo.gc.ca/Library/40713271.pdf

Dowle M, Srinivasan A (2017) data.table: rxtension of 'data.frame'. R package version 1.10.4-2. https://CRAN. R-project.org/package=data.table

Faraway JJ (2016) Extending the linear model with R: generalized linear, mixed effects and nonparametric regression models, $2^{\text {nd }}$ edn. CRC press, Boca Raton, FL

Grémillet D, Welcker J, Karnovsky NJ, Walkusz W and others (2012) Little auks buffer the impact of current Arctic climate change. Mar Ecol Prog Ser 454:197-206

Guillemette M, Grégoire F, Bouillet D, Rail JF, Bolduc F, Caron A, Pelletier D (2018) Breeding failure of seabirds in relation to fish depletion: Is there one universal threshold of food abundance? Mar Ecol Prog Ser 587:235-245

Gulka J, Carvalho PC, Jenkins E, Johnson K, Maynar L, Davoren GK (2017) Dietary niche shifts of multiple marine predators under varying prey availability on the northeast Newfoundland coast. Front Mar Sci 4:324

* Harding AMA, Piatt JF, Schmutz JA, Shultz MT, Van Pelt TI, Kettle AB, Speckman SG (2007) Prey density and the behavioral flexibility of a marine predator: the common murre (Uria aalge). Ecology 88:2024-2033

Hedd A, Regular PM, Montevecchi WA, Burke CM, Buren AD, Fifield DA (2009) Going deep: murres dive into frigid water for aggregated, slow-moving capelin. Mar Biol 156:741-751

Hijmans RJ (2016) Raster: geographic data analysis and modeling. $\mathrm{R}$ package version 2.5-8. https://CRAN.Rproject.org/package=raster

Kadin M, Olsson O, Hentati-Sunberg J, Willström Ehrning

Editorial responsibility: Kyle Elliott,

Sainte-Anne-de-Bellevue, Québec, Canada
E, Blenckner T (2016) Common guillemot Uria aalge parents adjust provisioning rates to compensate for low food quality. Ibis 158:167-178

Montevecchi WA (2000) Seabirds. In: Bundy A, Lilly, GR, Shelton PA (eds) Mass balance model: the Newfoundland Shelf. Can Tech Rep Fish Aquat Sci 2310:15-18

Montevecchi WA, Tuck LM (1987) Newfoundland birds: exploitation, study, conservation. Nuttall Ornithological Club, Cambridge, MA

Nettleship DN, Evans PGH (1985) Distribution and status of the Atlantic Alcidae. In: Nettleship DN, Birkhead TR (eds) The Atlantic Alcidae. Academic Press, London, p 53-154

Oro D (2014) Seabirds and climate: knowledge, pitfalls and opportunities. Front Ecol Environ 2:79

Österblom H, Olsson O, Blenckner T, Furness RW (2008) Junk-food in marine ecosystems. Oikos 117:967-977

Pebesma E (2017) sf: simple features for R. R package version 0.5-4. https://CRAN.R-project.org/package=sf

* Penton PM, Davoren GK (2012) Physical characteristics of persistent deep-water spawning sites of capelin: importance for delimiting critical marine habitats. Mar Biol Res 8:778-783

Pettex E, Lorenstein SH, Grémillet D, Gimenez O and others (2012) Multi-scale variability in northern gannet (Morus bassanus) fuels potential foraging plasticity. Mar Biol 159:2743-2756

* Piatt JF, Harding AMA, Shultz M, Speckman SG, van Pelt TI, Drew GS, Kettle AB (2007) Seabirds as indicators of marine food supplies: Cairns revisited. Mar Ecol Prog Ser 352:221-234

R Core Team (2017). R: a language and environment for statistical computing. R Foundation for Statistical Computing, Vienna

Regular P, Montevecchi W, Hedd A, Robertson G, Wilhelm S (2013) Canadian fishery closures provide a large scale test of gillnet bycatch on seabird populations. Biol Lett 9: 20130088

Regular PM, Hedd A, Montevecchi WA, Robertson GJ, Storey AE, Walsh CJ (2014) Why timing is everything: energetic costs and reproductive consequences of resource mismatch for a chick-rearing seabird. Ecosphere 5:155

Rose GA (1998) Acoustic target strength of capelin in Newfoundland waters. ICES J Mar Sci 55:918-923

* Storey AE, Ryan MG, Fitzsimmons MG, Kouwenberg AL and others (2017) Balancing personal maintenance with parental investment in a chick-rearing seabird: physiological indicators change with foraging conditions. Conserv Physiol 5:cox055

Sydeman WJ, Poloczanska E, Reed TE, Thompson SA (2015) Climate change and marine vertebrates. Science 350: 772-777

Wickham H (2016) ggplot2: elegant graphics for data analysis. Springer-Verlag, New York, NY

Wilhelm SI, Robertson GJ, Ryan PC, Tobin SF, Elliot RD (2009) Re-evaluating the use of beached bird oiling rates to assess long-term trends in chronic oil pollution. Mar Pollut Bull 58:249-255

Wilhelm SI, Mailhiot J, Arany J, Chardine JW, Robertson GJ, Ryan PC (2015) Update and trends of three important seabird populations in the western North Atlantic using a geographic information system approach. Mar Ornithol 43:211-222

WWorm B, Tittensor DP (2011) Range contraction in large pelagic predators. Proc Natl Acad Sci USA 108:11942-11947

Submitted: December 18, 2018; Accepted: August 2, 2019

Proofs received from author(s): September 14, 2019 